\title{
Factors Affecting the Intellectual Capital Disclosure Index: Evidence from Indonesian listed companies
}

\author{
Ali Sandy Mulya, Dewi Puspaningtyas Faeni
}

\begin{abstract}
The financial statements have not been able to present the existence of intellectual capital in an enterprise. In accordance with the Signalling theory, the company's Board of Directors try to present a positive signal to stakeholders by presenting the existence of intellectual capital through the annual reports. In fact, the disclosure of the existence of the intellectual capital as measured by the Intellectual Capital Disclosure Index turns out different This includes insurance companies which in its operational often use intellectual capital. The research objectives are to find the determinant of the disclosure of intellectual capital on the insurance companies listed in the Indonesia Stock Exchange (IDX) using the method of the multiple linear regression testing. The test results showed simultaneously the size of corporations, the age company, return on equity, a measure of the frequency of meetings of Commissioners and how the Commissioners' influence has a significant effect against the disclosure of intellectual capital. The implication is to open ways for academics to conduct the next research on intellectual capital in insurance companies and add new horizons of research on insurance in Indonesia which are still scarce.
\end{abstract}

\section{Foreword}

\subsection{Research Background}

Companies that implement a strategy knowledge-based business create value by managing the hidden values in intangible assets. One approach used in the assessment and measurement of intangible assets is through intellectual capital (Guthrie, 2004). Models of categories or components of intellectual capital that is already widely accepted are human capital, relational capital, and structural capital (Pablo, 2003). In order to maintain the competitive position of the company, the investment must be made using the intellectual capital components such as human resources, research and development (R\&D), and information technology (Canibano et al., 2000). Most of the investment in intellectual capital could not be capitalised into assets and should be by using revenue expenditure, so that it becomes the burden of the current period. PSAK No. 19 in 2012 about Intangible Assets of the adoption of the International Accounting Standard (IAS) No. 38 does not allow expenses for employee education as expenditure for intangible assets as far as the company does not have the power to prevent employees to resign from the company (PSAK 19, 2012) [12].

Revised Manuscript Received on July 05, 2019.

Ali Sandy Mulya,

Lecturer of Faculty of Economics and Business, Universitas Budi Luhur, alisandy@outlook.com
As a result the company's financial position reports cannot present the current existence of intellectual capital (Canibano et al., 2000), so that an increase in the difference between the book value and the market value of the company is evidence that traditional accounting is not beneficial because it cannot describe the full value of the company (Lev, 2001).Companies increasingly rely on intellectual capital, while the usage of traditional accounting will decrease in presenting company's financial health. The appropriate approach is to increase the value to enhance the financial statement disclosure of information concerning the assets [3].

Disclosure of information concerning the assets of the knowledge which became known by the name of intellectual capital in the annual report has become an interesting theme, given the intellectual capital is one of the information needed by investors to assess the company's ability to create wealth in the future (Goh \& Lim, 2004). Some studies also show high urgency disclosure of intellectual capital. One of them, namely the research conducted by Price Waterhouse Coopers who found that five out of the ten information needed by the user is information on intellectual capital [4].

Most literature on disclosure of intellectual capital was a descriptive study that does not test the reason of the difference in level between the company's intellectual capital disclosure (Whiting \& Miller, 2008). Meanwhile, other researches has tested any other factors that may affect the practice of the disclosure of intellectual capital, the results are inconsistencies because there is a difference in the test results of several variables that predicted the determinant of disclosure of intellectual capital. This is in line with the research of Bruggen et al. (2009) that in the intellectual capital there has not been a definite and clear results regarding factors that become a determinant of disclosure of intellectual capital [5].

This research examines what factors predicted that affect the disclosure of intellectual capital presented in the annual report of the company. These factors include the size of the company, the age of the company, the application of good governance by measuring the number of Commissioners, the Board of Commissioners meetings, as well as the profitability of the company by using return on equity (ROE). As for the reason for choosing an insurance company as an object of

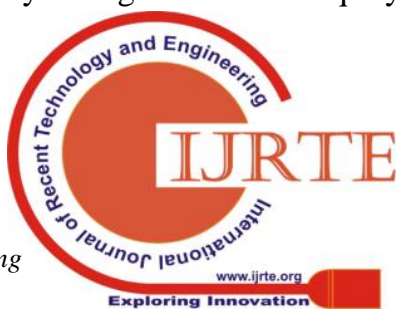


research: (a) the insurance industry as the financial services industry, in its operation relies heavily on the employees' capabilities and reliability of the operating system as well as the business network where it becomes the third element in the intellectual capital, (b) some insurance company's stock sale to foreigners in the last few years with prices that are more than the book value indicates the high value of intellectual capital in the insurance company, for example Mitsui Sumitomo Insurance Co., Ltd took over the 50\% shares of PT Sinarmas life insurance by paying Rp 8 trillion (press release PT AJS. 01 May 2011), roughly eight times the book value, (c) the lack of research on accounting in the insurance industry [6.]

\subsection{Motivation and Research Question}

The extent of the construction built and based background as described above, this research motivated model of influence of the company's size, age of firm, return on equity, frequency of Commissioners meetings and influential Commissioner against disclosure of intellectual capital, was formulated in the form of the questions as follows:

a. What is the size of the company's influence on disclosure of intellectual capital?

b. Whether the age of the company has influence on disclosure of intellectual capital?

c. What is the return on equity effect on the disclosure of intellectual capital?

d. Whether the size of the influential Commissioners has an effect against the disclosure of intellectual capital?

e. What is the frequency meetings of influential Commissioners against disclosure of intellectual capital?

f. Whether the size of the company, age of firm, return on equity, frequency of Commissioners meetings and size of influential Commissioners has any effect on the disclosure of intellectual capital?

Whereas the purpose of this research was to examine how far the factors that affect the disclosure of intellectual capital are presented in the annual report of the company[7]. These factors include the size of the company, the age of the company, the application of good corporate governance by measuring the number of Commissioners and defining the Board of Commissioners meetings, as well as the company's profitability as measured from the ROE. [8]

\section{Grand Theory}

\section{1. $\quad$ Signalling Theory}

The Signalling Theory is one of the pillars of the theory in understanding accounting. In general, the signalling theory is defined as gestures made by the company (the agent) to outside parties (investors). These signals can be in many forms, both of which can be observed directly or who require more in-depth study to understand it. Any form or signal type, will imply something towards the market expectations or whether external parties can change their judgement over the company, or in other words the signal emitted should have the power to change the assessment information to external parties upon the company [9].

Agents can increase the value of the company by way of reducing asymmetric information, one trick is to give a signal to outside parties in the form of reliable financial information so as to reduce the uncertainty about the company's prospects in the future. A report on the performance of good companies will increase the value of the company.

\subsection{Intellectual Capital Disclosure}

Currently the disclosure of intellectual capital demand continues to rise, the reason is that the accounting traditional assets can no longer be the largest component to account for the market price of the company (Ballow et al., 2004). Research results Ballow et al. in 2004 concerning the ratio of the market against the book value on a company incorporated in the United States in the 500, S\&P pointed out that during the 20 years before the research carried out $80 \%$ of the market price can be explained by accounting traditional assets. But since 2003 , only $15 \%$ of the market to book value ratio can be explained by accounting traditional assets. Ballow et al. (2004) concluded that the cause is that there is another asset which cannot be covered by the traditional accounting and assets is called the intellectual capital [10].

In Indonesia, not all intellectual capital can be reported as an asset in the financial statements of the company, because it does not meet the definition of recognition of assets in the conceptual framework. PSAK 7 (2012) States that the intangible asset is recognised if and only if it is likely that the company will benefit economically from the asset's future, and the cost of acquisition of the asset can be measured reliably and, in the assets, controlled by the company. Such recognition criteria, it will be very difficult to be able to recognize all intellectual capital as intangible assets in the financial statements of the company [11].

Disclosure of intellectual capital is still in development and still less defined in annual reports (Vergauwen et al., 2007). In General, disclosure of intellectual capital contains a wide range of financial and non-financial information such as rotation of employees and job satisfaction, employee training, customer satisfaction, the burden of research, development and so on. Mouritsen et al. (2001) found that the disclosure of intellectual capital is 
complex because it can contain numbers, narratives, and visualizations, for it is a description that can be used to represent information about intellectual capital that are quantitative or qualitative[12].

The company revealed in its annual report on intellectual capital, can be measured by one way is referred to as a content analysis of the annual report. Et.al Guthrie (2004) states that the content analysis is a method for measuring the level of disclosure of intellectual capital. This technique is a way of collecting data by making the code in a systematic, objective and quantitative information based on reliability, as well as qualitative into categories that have been determined to obtain the pattern in reporting information. Typically, this technique produces an index concerning the level of reporting of intellectual capital. The components that will be used to conduct a content analysis to the practice of disclosure of intellectual capital in this study will be adopted from the list item (Li et al.,2008) [13].

Average ICDI (Intellectual Capital Disclosure Index) insurance companies listed in the stock exchange of $48.20 \%$ with a standard deviation that is low. The chart below shows that insurance companies have a tendency of increasing ICDI even by 2014 reaching the average of $56,47 \%$. The highest attained by the ICDI LPGI company of $72,13 \%$ in 2014 [14-15].

\section{Research Framework}

In accordance with the theory of signal, the Manager seeks to reveal the good news to the stakeholders to reduce information asymmetry (Olievera et al., 2006). The disclosure could be a signal that can be reliable, so that the market value of shares of the company can reflect corporate values (Hughes, 2007).

This study tries to analyse the extent to which this type of industry, size of company, company's age, return on equity, a measure of the Commissioner as well as the frequency of meetings the Commissioner affect disclosure of intellectual capital in the insurance companies listed on the Indonesia Stock Exchange (IDX). Based on the above, the exposure model framework this study displayed on

\section{Research Method}

\subsection{Research Design}

This pertained to the research in the study of causality, namely the research analysing the relationship between the causal variables (independent) with a bound variable (dependent). This study uses secondary data i.e. annual report companies listed on the Indonesia stock exchange (BEI) in the period 2006-2014 that is downloaded from the BEI official site.

\subsection{The Population, Sample and Method of Data} Collection
The population of this research is the insurance companies which are listed on the Indonesia stock exchange (BEI) in the period 2006 until 2014. As many as 9 companies with 81 observations. The method of selection for the companies as samples used in this research is purposive sampling, namely samples taken from certain considerations based on destination (Sekaran, 2011). The sampling criterias are as follows:

1. Insurance Company registered in BEI in 2006 up to the year 2014.

2. Publish their annual report from 2006 up to the year 2014.

3. The delisting is not during the period between $2006-$ 2014

4. Insurance Company.

\subsection{Operational Variable}

Operational Variable can be explained as follows:

The Dependent Variable (Y) in this study is the Intellectual Capital Disclosure Index (ICDI) calculated by doing a content analysis over the company's annual report. Components that are used to measure the level of disclosure of intellectual capital is a component taken from $\mathrm{Li}$ et al (2008). Li et al. (2008) developing a comprehensive listing of information about intellectual capital consisting of 61 components that are the result of a review of several previous research (such as the Guthrie and Petty, 2007; Bozzolan et al., 2003; Beattie and Thomson, 2004). In line with previous research (Guthrie et al., 2007; Li et al., 2008, Vergauwen and URet.al., 2007 and Mangena, 2010) and the purpose of this research, intellectual capital disclosure components is divided into human intellectual capital, intellectual capital, structural capital and relational intellectual. The size of human capital disclosure (HCDI) consists of 22 components, structural capital disclosure (STCDI) is composed of 18 components, and relational capital disclosure (RCDI) is composed of 21 components. So, there will be 61 components that will be analysed.

To create intellectual capital disclosure index, we utilise content analysis of the annual report with the technique of "presence" and "absence". Each item is given a score of 1 if a company conducts disclosure over the item, and a score of 0 when not doing the disclosure. This score will then be combined with the rest of the scores obtained in each category and valued with a total of items per category so that we can obtained indexes for each category. Intellectual capital disclosure index is the total index of the three categories that comprise human capital, structural capital and relational capital.

The ratio of the level of disclosure of intellectual capital 
of each company is obtained by dividing the total score disclosure on any company with total items in index disclosure of intellectual capital.

\subsection{The Independent Variable (X)}

a. The size of the company (X 1) Company Size can be specified in various ways such as the large amount of assets, the amount of equity, the large amount of sales, the value of market capitalization. The research uses logarithm of natural equity. Do not use total assets due to the application of the SAK No. 1 (revised 2009) regarding the presentation of the financial statements which began to be applied to the total asset causes 2011 insurance and reinsurance is distorted.

b. The age of the company (X 2) can be measured from the time of its establishment. However, many studies use age listings, that is how long the company has been listed on the stock exchange, in a study using data from a company that has been listed on the stock exchange. Measured age of the company since its establishment up to the year annual report, stated in increments of 6 months are considered one year old.

c. Return on Equity (X 3) (ROE) is a measure of the level of corporate profits are calculated after of taxes net profit, divided by the number of the company's equity.

d. The size of Commissioner (X 4) Variable Size is taken from the number of Commissioners reported in the annual report. The Commissioner in size includes the number of independent Commissioners.

The frequency meeting of the Commissioners (X 5) Variable is defined by the frequency of meetings the Commissioner is taken from the number of times the Commissioner Board of Commissioners convenes in one fiscal year, data are obtained from the annual report.

\subsection{Data Analysis Method}

The data to be analysed is the data panel that is a combination of a time series data and cross section data. The data panel is often also called pooled data, data micro panel, longitude data, event history analysis, and cohort analysis (Ghozali \& Ratmono, 2013). Ghozali \& Ratmono (2013) stated that the usage of the data panel has some major advantages compared with a of time series or cross section, namely:

1. The Data panel can provide a large number of observations of researchers, increasing the degree of freedom, has a large variability of data and reduce collinearities between independent variable so that it can generate efficient econometric estimation.

2. The Data panel can provide much more information which cannot be given only by the data time series or cross section only.

3. The Data panel may provide a better settlement in dynamic changes than inference data cross section.
Data analysis will use software EViews 9 developed by Quantitative Micro Software (QMS) as successor to the TSP program. The Program was chosen because of its ability to cultivate the reviews of various types of data such as the cross-section, time series and panel.

\section{Research Analysis Result and Research Discussion}

\subsection{Data Analysis Result}

In this regression analysis result we utilize the linear multiple regression with the following equation:

$$
\begin{aligned}
& \mathbf{Y}=\boldsymbol{\alpha}+\boldsymbol{\beta 1 X 1}+\boldsymbol{\beta 2 X} \mathbf{2}+\boldsymbol{\beta 3 X 3}+\boldsymbol{\beta 4 X} \mathbf{4}+\boldsymbol{\beta X} \mathbf{5}+\mathbf{\boldsymbol { \varepsilon }} \\
& \text { Remarks: } \\
& \mathrm{Y}=\text { Intellectual Capital Disclosure Index (ICDI) } \\
& \alpha=\text { Constant } \\
& \beta=\text { Slope } \text { or regression coefficient } \\
& \mathrm{X} 1=\text { Size of Corporation } \\
& \mathrm{X} 2=\text { Age of Corporation } \\
& \mathrm{X} 3=\text { Return on Equity (ROE) } \\
& \mathrm{X} 4=\text { Size of Commissioner } \\
& \mathrm{X} 5=\text { Commissioner Frequency Meetings } \\
& \grave{\varepsilon}=\text { Error }
\end{aligned}
$$

Testing was done with software EViews 9 using the Ordinary Least Square (OLS) by using a fixed effect model. The test results are displayed in

$$
==\text { appendix } 1 \text { === }
$$

\subsection{Test Result Discussion}

a. The effect of corporation size against the Intellectual Capital Disclosure Index (ICDI).

The corporation size affects the ICDI shown in the probability variable ( $\mathrm{sig}$ value) of corporation size $=$ $0.0475<0.05$. The test result shows that it is similar with the research from Oliviera et al. (2006) that shows that there is a significant positive effect on the company size against ICDI. This is due to the fact that there is a regulation from OJK that the minimum equity of an insurance company has to be at least Rp. 100 billion and 200 billion for reassurance company and they must meet the requirements by the end of 2014, therefore insurance companies should increase their equity to meet OJK's requirements, thus simultaneously increase their ICDI.

a. The effect of corporation age against the Intellectual Capital Disclosure Index (ICDI).

Corporation age affects the ICDI shown in the probability variable ( $\mathrm{sig}$ value) of corporation age $=$ $0.0000<0.05$. The test result shows that there is an effect on the corporate age towards IDCI, meaning that the higher the age of the company, the higher its effects on the IDCI. This is in accordance to the research by White et al. (2007) that had undertaken a research on a biotechnology company.

b. The effect of ROE against the Intellectual Capital Disclosure Index 
(ICDI).

ROE did not show any significant effect on the IDCI shown in the probability variable (sig value) $\mathrm{ROE}=$ $0.0829>0.05$. The test result is in accordance to the research conducted by Meca and Martinez (2005) on 257 corporate reports listed in the Madrid, Spain stock exchange. The test result is not in accordance to the signalling theory because the corporation did not give a positive signal to decision makers to disclose the condition of the corporation in the yearly report.

c. The effect of corporate size against the Intellectual Capital Disclosure Index (ICDI).

Corporate size has an effect on the ICDI shown in the probability variable (sig value) corporate size $=0.0422<$ 0.05 . The test result is in accordance to the research conducted by Li et. al. (2008) on 100 companies listed in the London Stock Exchange in the year 2004 and 2005, showing that all proxy corporate governance and the commissioner size has an affect towards the IDCI. The Commissioner in this case do not limit the disclosure of IDCI to their competitor.

d. The effect of the commissioner frequency meetings against the Intellectual Capital Disclosure Indeks (ICDI). The commissioner frequency meetings does not have a significant effect towards the IDCI probability variable $($ sig value $)=0.4947>0.05$. The test result shows that it is not in accordance to the research conducted by Faniyya and Sudarni (2012) on the yearly report of 100 companies listed in the Indonesia Stock Exchange (IDX), showing that the commissioner frequency meetings have a significant positive effect on the IDCI.

The test result shows that it isn't in the frequency of the meetings that has an effect, but how intense the board of commissioners supervise the board of directors that are represented in the commissioner frequency meetings is what is more likely to have an effect on the IDCI.

e. The effect of company size, the age company, return on equity, the number of Commissioners, the frequency of meetings of Commissioners together against intellectual capital disclosure index (ICDI).

Determination of test results that yield coefficient (adjusted R-squared) of $92 \%$ indicated that the company's size, age of firm, return on equity, the number of Commissioners and the frequency of meetings the Commissioner very strongly affect the disclosure of intellectual capital in the company.

\section{Conclusions, Implications Research}

\subsection{Conclusion}

This research aims to examine the factors that affect the disclosure of intellectual capital. Factors examined in this study is the size of the company, the age of the company, the ROE, the amount and frequency of meetings of Board of Commissioners the Board of Commissioners. Some of the conclusions that can be drawn from the test results in this research are as follows:

1. The disclosure of intellectual capital in the insurance company is an average of $48.2 \%$ of 61 items, the disclosure is still classified as low. The preparation of the annual report of the company refers to regulations No. OJK X.K. 6 about the obligation of submission of annual reports for the Issuer or public company that is mandatory so that intellectual capital disclosure emphasizes only on certain aspects of the rules.

2. Overall, there is a tendency of increased disclosure of intellectual capital from the period 2006 until 2014.

3. The size of the company research results using proxy total equity. Most likely this is caused because the insurance company in the period of 2010-2014 concentrate to improve their equity to meet conditions regarding minimum equity from OJK and level of financial health. The increase in equity is not offset by increased disclosure of intellectual capital, so statistically it has negative effect.

4. The increased ICDI Charts indicate that the more companies realize the necessity of voluntary disclosure of insurance companies over the whereabouts of their intellectual capital. The realization that the cornerstone of the insurance business is the trust of the policy holder/insured to the insurance company should be incentive for the company to give a positive signal to stakeholders including the insured/policyholder by revealing the existence of intellectual capital in the annual report.

\subsection{Implications}

1. Insurance companies in Indonesia should already enhance the trust of the policy holder and other stakeholders by providing broader disclosure over the existence of intellectual capital.

2. If insurance companies and reinsurance regulatory improvement will occur in the disclosure of intellectual capital. The indications will already be visible from the graphic of the ICDI which will rise sharply in 2014, as we can observe in the illustration below.

3. Opening the way for further research on intellectual capital in insurance companies and add to the corpus of research on insurance in Indonesia which are still few in number.

Ethical clearance - Not required

Source of funding- Self

\section{Conflict of Interest - Nil}

\section{References}

[1] Ballow, J., Burgman, R. and Molnar, J. (2004), 
agingManaging for shareholder value:

[2] intangibles, future value and investment decisionsll, Journal of Business Strategy, Vol. 25 No. 3, pp. 26-34

[3] Beattie, V. and Thomson, S.J. (2007). Lifting the Lid on the Use of Content Analysis to Investigate Intellectual Capital Disclosures, Accounting Forum, 31: 129-163.

[4] Canibano, L., Garcia-Ayuso, M. and Sanchez, P. (2000). The Value Relevance and Managerial Implications of Intangibles: A Literature Review. The Journal of Accounting Literature, 19, 10230.

[5] Ghozali, Imam and Dwi Ratmono (2013). Multivariate Analysis and Econometrics, Theory, Concepts and Applications with Eviews 8. Diponegoro University Publishing Agency.

[6] Goh, P.C and K.P, Lim. (2004). Disclosing Intellectual Capital in Company Annual Reports: Evidence from Malaysia. Journal of Intellectual Capital.5, 3: 500

[7] Guthrie, J., Petty, R., Yongvanich, K. and Ricceri, F. (2004). Using Content Analysis as A Research Method to Inquire Into Intellectual Capital Reporting. Journal of Intellectual Capital, 5 (2), 282-93.

[8] Hughes, JS., Liu, J and Liu, J. (2007). Information Asymmetry Diversification and Cost of Capital. The Accounting Review; May 2007; 82, 3: pg. 705 .

[9] IAI (2012), Statement of Accounting Standards No. 19: Intangible Assets. Indonesian Accountants Association.
[10] IASB (2002). International Accounting Standards Committee Foundation, Annual Report, London: International Accounting Standards Board.

[11] Li, J., Pike, R. and Haniffa, R. (2008). Intellectual Capital Disclosure and Corporate Governance Structure in UK firms. Accounting and Business Research, 38 (2), 137-159.

[12] Mangena, M., Pike, R. and Li, J. (2010) Intellectual Capital Disclosure Practices and Effects on the Cost of Equity Capital: Uk Evidence, The Institute of Chartered Accountants of Scotland, Edinburgh

[13] Pablo, Patricia Ordenez. (2003). Intellectual Capital Reporting in Spain: a comparative review. Journal of Intellectual Capital. Vol. 4 No. 1: 61-81.

[14] Sekaran, Uma and Bougie, R. (2011). Research methods, for business spill building approaches, John Wiley \& Sons Ltd, The Atrium, Southern Gate, Chichester, WestSussex, PO19 8SQ, United Kingdom.

[15] Vergauwen, P., Bollen, L, and Oirbans, E. (2007). Intellectua Capital Disclosure and Intangible Value Drivers: An Empirical Study. Journal of Intellectual Capital, 45 (1), 1163-1180. 
International Journal of Recent Technology and Engineering (IJRTE) ISSN: 2277-3878, Volume-8 Issue-2S4, July 2019

$===$ Appendix $1====$

FIXED EFFECT MODEL

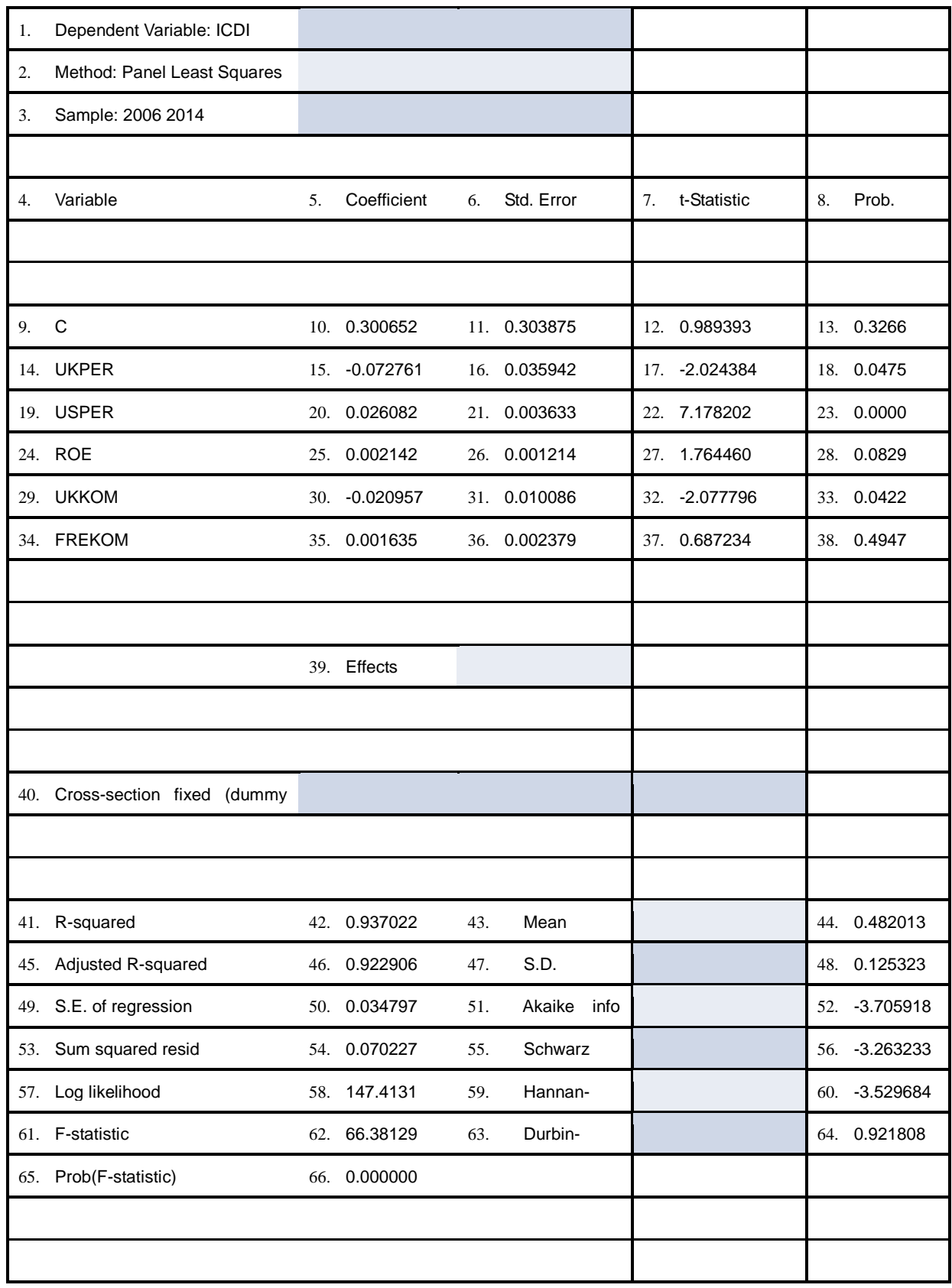

